\title{
The intention to purchase designed fashion product of Vietnamese Designer: The mediator of customer relationship
}

\author{
Bui Thanh Khoa \\ Truong Duy Nguyen \\ Van Thanh-Truong Nguyen \\ Industrial University of Ho Chi Minh City, Ho Chi Minh City, Viet Nam
}

\section{Keywords}

Designer Reputation Belief, Social Media Communication, Fashion Store Environment, Customer relationship, Intention to purchase, Designed fashion product.

\begin{abstract}
Customer relationship management is an essential activity for business because customer relationship becomes a critical concept between business and consumer behavior. The need for fashion is emerging as an essential human need, not only in developed countries but also in developing countries like Vietnam. The purpose of this study is to define the constructs related to the fashion designer, which will impact the customer's purchase intention under the mediator of the customer relationship. The primary research methodology is a quantitative research method with the survey via a questionnaire. Through a survey of 567 consumers, the research has shown that fashion designer reputation belief, social media communication, and fashion store environment are the antecedents of the customer relationship. Moreover, customer relationship is the mediator of the above factors and the intention to purchase designed fashion product. The study contributed to confirm the relationship theory in the fashion industry, especially in designed fashion products, which is not concerned by the researchers in the past. Furthermore, the study proposed some managerial implications related to the fashion designer reputation belief, social media communication, and fashion store environment for fashion designers.
\end{abstract}

Corresponding author: Bui Thanh Khoa

Email addresses for the corresponding author: buithanhkhoa@iuh.edu.vn, khoadhcn@gmail.com

First submission received: $27^{\text {th }}$ December 2019

Revised submission received: $26^{\text {th }}$ February 2020

Accepted: 23 ${ }^{\text {rd }}$ March 2020

\section{Introduction}

Product competition seems to be no longer in a stage where all businesses can create products of similar quality. The customers choose a business to buy depends very much on their assessment of the care and support from business in all phases of the purchasing process. The concept of customer relationship management (CRM) is gradually becoming popular in a business environment with fierce competition among businesses in the same industry. In addition to practical application by business, CRM is also one of the interesting topics for researchers (Srinivasan and Moorman, 2005). CRM is the work of approaching and communicating with customers, managing customer information, thereby serving customers better and establishing sustainable relationships with them. In other words, based on the data and information collected from customers, the store will devise a reasonable and effective customer care strategy (Brink and Berndt, 2009). Customers are of importance to the businesses; therefore, businesses must focus on building, maintaining and developing long-term relationships with them. Hence, relationships with customers are also objects that need to be managed. CRM is based on four principles, including (1) customers should be managed as an essential asset, (2) all customers are not the same, (3) customers are different in demand, tastes, buying behavior, (4) there is the better understanding the customer behavior to help business supply well, maximize the entire value. The more an enterprise understands customers, the more excellent its opportunity to enter the market and the contribution of customers (Kutner and Cripps, 1997).

Mentioning fashion is about the beauty trend of people. In order to do good business and have a high profit in the fashion industry, the enterprise must first know how to understand the behavior of 
target potential customers better. Human life is increasing day by day, so human needs are also growing more and more. One of the increasingly demanding fields of people is the fashion market. Trends in recent years, the shopping needs of consumers increased sharply. In the current volatile environment, human demand is increasing, the demand for fashion is therefore growing. According to the most recent survey of the fashion market, including clothing and footwear in Vietnam in 2018, it was 3.8 billion USD, accounting for a significant proportion in the market of consumer products. Forecast for the coming years is still developing.

In the current fashion and clothing market, if classified into four customer groups according to the pyramid model respectively, from the bottom to up, fashion business will shape customer structure, as follows:

The lowest level (the bottom of the pyramid): The consumption power of this customer group is small. They are fashion buyers with low incomes, or who are entering the late middle age and before seniors. They are the ones who restrict buying clothes, or if they also buy ordinary products, affordable, they do not have much demand for fashion.

The second level: this group includes white-collar customers. The number of consumers in this group is enormous. They like to buy together, or they like promotional products, discounts, or a promotion program. In addition, these customers want convenience, fast, entertaining.

The third level: this group includes the customer with moderate and high-end income. They are office workers, and they have a car or go to work by taxi. These customers are in high demand for highlevel fashion.

The fourth level (the top of the pyramid): these are customers of the upper class, which is the rich in society. The fashion products that they use are branded, unique designs, even in the world.

Macintosh and Lockshin (1997) proposed that the positive relationship between the buyer and seller will lead to the purchase intention or repurchase of the customer. The core of CRM creates value for the customer. The purpose of the business is not only to maximize profits through every single transaction but to build a long-term, sustainable relationship with customers through the use of their capabilities. As such, CRM requires the business to understand the process by which customers create value to help customers enhance the value they receive. The designed fashion market is different from the fast fashion market. Designed fashion products are to target specific groups of customers rather than the general public. Therefore, the customer of the designed fashion product will belong to the third and fourth levels of the pyramid. They will choose the fashion product, which is designed the reputation designer, known via social media communication, and attracted them by the store environment when they come to the store. Three above dimensions are essential to affect the buyer decision process. Therefore, the study aims to find out the relationship between reputation designer, social media communication, store environment, and customer relationship, as well as the mediating role of customer relationship in the effect of independent factors on intention to purchase designed fashion products.

\section{Literature review}

\subsection{Fashion design and the Designed Fashion Product}

Fashion design is the creation, exploration, and research of man in order to create clothing products that satisfy the beauty needs. Fashion design consists of two directions, including performing art and practical application (Marzo-Navarro et al., 2004).

The fashion clothing business is a fascinating field. However, most of the shops sell the products sourcing from many unknown places, which is leading to poor quality, or similar models. Therefore, the designed fashion product for consumers is the "niche market" that many fashion companies or fashion designers are targeting. Customers will always be able to use the designed products because of good quality, guaranteed materials, new designs, sophisticated seams, and unique. One of the most substantial advantages of designed fashion products is not got duplication with others. Self-designed outfits will always have a unique, fresh, catch uptrend. Notably, customers can order the fashion product according to their size or their personality. 


\subsection{The theoretical model}

The study based on the Theory of Planned Behavior (TPB), which has been widely used in research and successful application as a theoretical framework to predict intention and buying behavior. TPB was developed by Ajzen (1991) based on the Theory of Reasoned Action (TRA) of Ajzen and Fishbein (1975) by adding the construct "perceived behavioral control" to TRA. Perceived behavioral control reflects how easy or difficult it is to engage in behavior, depending on the availability of resources and the opportunities to engage in the behavior. According to TPB, customers' "intention of behavior" is affected by "attitudes," "subjective norms," and "perceived behavioral control." TPB has been widely accepted and used in studies to predict individuals' specific intentions and behaviors. Hansen et al. (2004) tested both TRA and TPB models, and the results showed that the TPB model explained customer behavior better than the TRA model. Moreover, empirical studies have shown the suitability of this model in studying consumer behavior in the many contexts generally, and fashion context (Widyarini and Gunawan, 2017).

In the context of designed fashion products, the customer knows or admires an individual designer. Therefore, the designer reputation belief is an essential factor that influences the customer's decision to purchase the fashion product. The reputation of designers is formed through the positive attitude of customers due to expertise, or awards in the fashion design area. As such, the belief in the reputation of the design is seen as a consumer attitude in the decision-making process of shopping. In addition, as the internet and social networks have grown, traditional subjective standards have shifted to the online environment. Customers search for information through forums or social networking sites. Social networking sites of fashion brands become the best communication channel to take care of, answer questions for customers, and become a new subjective norm in the modern context. One of the crucial issues affecting the intention to buy fashion in stores is the appropriateness of the size and style of the product to customers. Therefore, besides product quality, designers also invest in the environment of the store in order to increase the purchasing intent of consumers. Consumers often prefer to shop at a store with a consultant for fashion trends, or to have a convenient decor for searching. These factors help in the decision making of the customer. Some customers go shopping for relaxing and reducing the stress in their life. The store environment is considered as the perceived behavioral control during shopping because it makes the customers purchase more efficiently in a store. Therefore, the store environment factor is an essential predictor of customer behavior in the field of fashion. Based on the TPB model; the authors proposed Designer Reputation Belief, Social Media Communication, Fashion Store Environment are the antecedents of the customer's intention to purchase the designed fashion product.

However, the development of relationship marketing theories has placed customer relationships at the heart of the business organization process and consumer behavior, which is pointed out critically in the Relational Mediator Meta-Analytic Framework (Palmatier et al., 2006). Today, customers make a behavioral decision not only by the influence of the seller but also through the perceived relationship between the seller and the buyer (Brink and Berndt, 2009; Nguyen and Khoa, 2019b). Hence, the authors have assumed customer relationship is a mediator in the relationship between three constructs (Designer Reputation Belief, Social Media Communication, Fashion Store Environment) and the purchase intention of the customer in the fashion industry. Consequently, the theoretical model is proposed in Figure 1.

\subsection{Intention to purchase designed fashion product (ITP)}

The intention is a construct which used to assess the likelihood of future behavior (Engel et al., 1982), and purchase intention expresses, "What we think we will buy" (Blackwell et al., 2006). Consumers who intend to shop online refer to their readiness to purchase in an online store. Typically, this factor is measured by consumers' willingness to buy and return to buy more. According to Ajzen (1991), the intention is a motivating factor, it motivates an individual to be willing to perform acts and it is an influential factor in behavior. The intention to purchase a product is also expressed through positive thinking about the future purchase of the product by the consumer (Khoa, 2018). Therefore, the Intention of purchase designed fashion products includes the intention of buying designed fashion products soon, positive thoughts about buying designed fashion products, or buying designed fashion products when they need a fashion product for daily activities. 


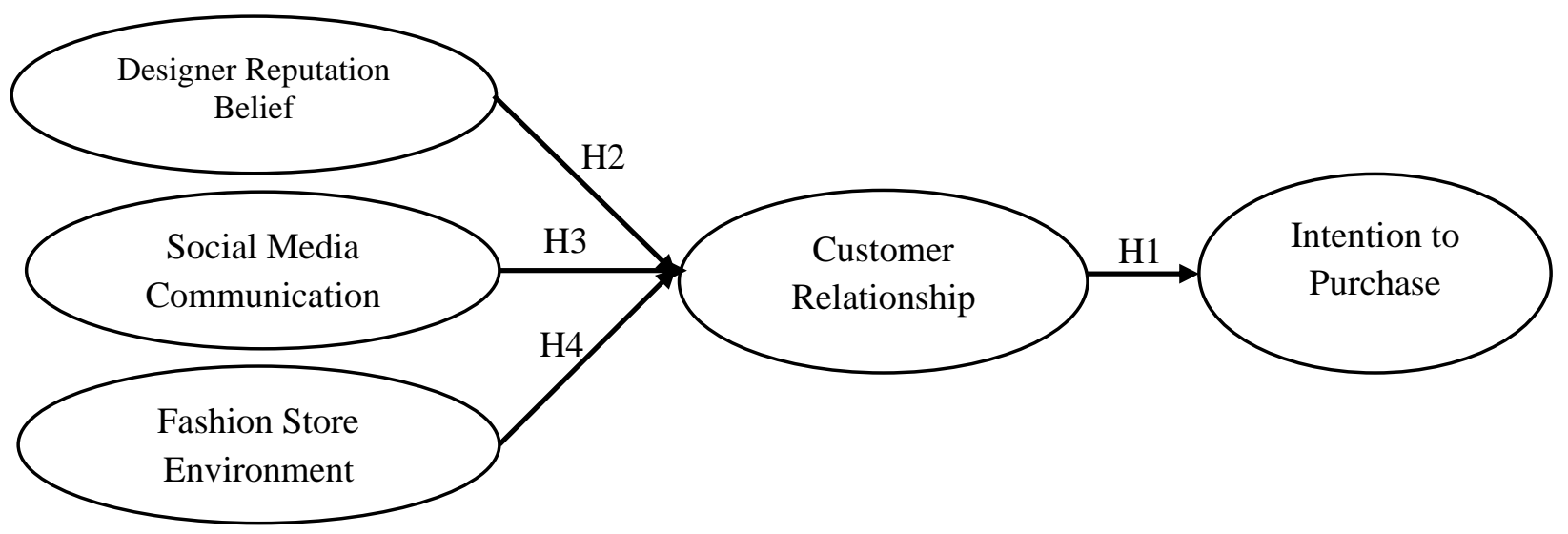

Figure 1. The theoretical model

\subsection{Customer Relationship (CR)}

Customer relationship is to find, attract, win new customers, maintain existing partners, entice returning customers, reduce marketing costs, and expand customer service (Brink and Berndt, 2009). Measuring and evaluating customer relationships is very important in the strategic implementation goal (Reinartz and Kumar, 2003). Customer information will be updated and stored in the database management system through the CRM system. Thanks to a unique data tracking tool, the business can analyze and form long-term and potential customer lists to devise sensible customer care strategies. Besides, the business can handle customer problems quickly and effectively (Gronroos, 2007).

Morgan and Hunt (1994) also believed the customer relationship is a good starting point in a new relationship between the customer and business. The customer will have the purchase intention or remember the brand when they trust and commit to a fashion business (Kim and Ko, 2010; Nguyen and Khoa, 2019c). Hence, the customer relationship in the fashion business will push the customer to come and shop in the fashion store. Therefore, the study proposed the hypothesis:

H1: Customer Relationship has a positive impact on Intention to purchase designed fashion product

\subsection{Designer Reputation Belief (DRB)}

In this study, reputation refers to how well someone perceives them to be respected or empowered by participating in the fashion community. An individual creates his/her reputation by demonstrating expertise in fashion design and costume aesthetics (Ou et al., 2012). A good reputation also often accompanies a good physical and spiritual life, as well as a person who may have extraterritorial rights. On the other hand, just as the customer care about their values, reputation is also a core factor affecting business activities (Teece, 1998). A good reputation is not quickly built immediately but must be built up through a continuous process of performing particularly meaningful acts on a variety of occasions (Zinko et al., 2012). Based on the above arguments, the research hypothesizes that reputation also influences connection behavior and ties relationships in the designed fashion shopping community.

H2: Designer Reputation Belief has a positive impact on customer relationship in the designed fashion context

\subsection{Social Media Communication (SMC)}

The concept of social media was born a few decades ago with the advent of the early internet and the Bulletin Board System. However, it was not until the Web 2.0 platform came along, with technology that helped users build content and connect themselves, that the era of social media exploded. Social media is now understood as the platform that provides internet users based on web 2.0 technology (Edosomwan et al., 2011). Kaplan and Haenlein (2010) define social media as "internet applications built on the technology and ideal platform of web 2.0, which facilitate the creation and exchange of information by users". Murthy (2012) defines social media solely as a means of communication by which the public can create and exchange information on the internet. It is essential to note the difference between social media and social networks. In terms of technology, these two concepts are the same: they are web-based web 2.0 
platforms to help users can create and transmit information. However, the term social media has a broader meaning, including media and content, while social media puts more emphasis on the technology platform that creates it.

The marketing activities of fashion brands through social media will have a positive impact on customer relationships (Kim and Ko, 2010). Nguyen and Khoa (2019d) pointed out that perceived social interaction is one of the perceived mental benefits of the customer, and it leads to a long-term relationship with the customer. In particular, fashionistas have many fans in their social network, which becomes the new channel to maintain the relationship with the customer. Hence, a hypothesis is proposed:

H3: Social Media Communication has a positive impact on customer relationship in the designed fashion context

\subsection{Fashion Store Environment (FSE)}

The environment is present for the surrounding space at a particular location. When someone comes to the restaurant's environment, the customer will judge that the restaurant feels comfortable, or that the restaurant is crowded, maybe the restaurant is clean. Usually, the environment is perceived by the senses. The environment of a commercial space performs three functions, including attention, message (communication), and influence (Lovelock and Wirtz, 2008). The environment is the "silent language" in transmitting messages. The environment is a qualitative structure consisting of four of the primary senses, except for taste: sight (seeing), sound (hearing), fragrance (smell), light touch (touch). The environment is the result of the design and creation of space, places to buy, and salesperson to create emotions that affect buyers (Dunne et al., 2013; Jobber et al., 2019). Furthermore, beyond that, emotions affect customers' shopping activities as well as subsequent purchases at a particular store. Therefore, the hypothesis can be proposed:

H4: Fashion Store Environment has a positive impact on customer relationship in the designed fashion context

\section{Research methodology}

A convenient sampling method, with 586 respondents, was done. Survey respondents are the customers who will go shopping at the fashion stores in Ho Chi Minh City and know clearly about their designed fashion brand. Five hundred ninety pieces of the questionnaire were distributed, but four questionnaire pieces were excluded because the respondent delineated to one number in all the questions. Finally, 586 valid questionnaires and were used for subsequent processing. To make it easier for respondents, the first part of the questionnaire describes in detail the definition of a designed fashion to ensure that respondents understand the concept of the designed fashion field.

The research will adopt the scale in the previous research, which will be modified in the focus group discussion. After screening, modifying, five research constructs will include 20 items. Designer Reputation Belief has four items, including Talent, creativity, innovative designs, consistent style (Kawamura, 2004). Social Media Communication has five items including Customization, Entertainment, Trend, Interactivity, E-WOM Kim and Ko (2010). Fashion Store Environment has four items, including Music, Scent, Salesperson, Light/color (Parsons, 2011; Jobber et al., 2019). Customer relationship has four items, including Commitment, Trust, Relationship satisfaction, Relationship quality (Palmatier et al., 2006). Finally, Intention to purchase has three items, including positive thinking about buying, buying probably, the intention to buy (Khoa, 2018). The 5-point Liker scale will measure all the items in the research with one is the total disagree, and five is the total agree.

The characteristics of the sample were $325(55.5 \%)$, who were female, and $261(44.5 \%)$ of the respondents were male. In which $144(24.6 \%)$ respondents aged from 22 to 30, 139 (23.7\%) respondents in the sample were aged from 31 to 35, $172(29.4 \%)$ respondents aged from 36 to 45, the rest of sample $(22.4 \%)$ aged over 45 . Three occupations of respondents in the survey include housewife $(31.9 \%)$, whitecollar worker $(35.2 \%)$, and businessman $(32.9 \%)$.

The collected data will be processed by SmartPLS software 3.2.7 to prove the reliability, validity of the constructs in the research, test the hypotheses, and theoretical model.

\section{Result}

In the first step, the research will assess the reliability and validity (convergent validity, discriminant validity) of the constructs in the research via the criteria including Cronbach's Alpha (CA), Composite Reliability (CR), the Average Variance Extracted (AVE), and Heterotrait-Monotrait Ratio (HTMT). 
Table 1. The outer loadings, CA, CR, AVE.

\begin{tabular}{|c|c|c|c|c|c|c|c|c|}
\hline & $\mathrm{CR}$ & DRB & FSE & ITP & SMC & CA & $\mathrm{CR}$ & AVE \\
\hline CR1 & 0.881 & & & & & \multirow{4}{*}{0.912} & \multirow{4}{*}{0.938} & \multirow{4}{*}{0.792} \\
\hline CR2 & 0.868 & & & & & & & \\
\hline CR3 & 0.933 & & & & & & & \\
\hline CR4 & 0.877 & & & & & & & \\
\hline DRB1 & & 0.851 & & & & \multirow{4}{*}{0.935} & \multirow{4}{*}{0.951} & \multirow{4}{*}{0.795} \\
\hline DRB2 & & 0.780 & & & & & & \\
\hline DRB3 & & 0.938 & & & & & & \\
\hline DRB4 & & 0.896 & & & & & & \\
\hline FSE1 & & & 0.860 & & & \multirow{4}{*}{0.813} & \multirow{4}{*}{0.886} & \multirow{4}{*}{0.723} \\
\hline FSE2 & & & 0.856 & & & & & \\
\hline FSE3 & & & 0.861 & & & & & \\
\hline FSE4 & & & 0.843 & & & & & \\
\hline ITP1 & & & & 0.713 & & \multirow{3}{*}{0.878} & \multirow{3}{*}{0.916} & \multirow{3}{*}{0.731} \\
\hline ITP2 & & & & 0.913 & & & & \\
\hline ITP3 & & & & 0.909 & & & & \\
\hline SMC1 & & & & & 0.925 & \multirow{5}{*}{0.912} & \multirow{5}{*}{0.938} & \multirow{5}{*}{0.792} \\
\hline SMC2 & & & & & 0.898 & & & \\
\hline SMC3 & & & & & 0.887 & & & \\
\hline SMC4 & & & & & 0.890 & & & \\
\hline SMC5 & & & & & 0.856 & & & \\
\hline
\end{tabular}

According to Hair et al. (2016), the constructed assessment of reliability, convergent validity, discriminant validity will meet the below criteria:

The reliability of the construct will be measured via Cronbach's Alpha, which has the threshold is equal to or more than 0.7 .

The convergent validity will be proved via the Outer Loading, Composite Reliability, the Average Variance Extracted. In which, the threshold of CR is equal or more than 0.7, the threshold of AVE is equal or more than 0.5 , and the threshold of the Outer loading is equal or more than 0.708 .

The discriminant validity will be assessed through the Heterotrait-Monotrait Ratio (HTMT), with the threshold of HTMT between two constructs is lower than 0.85 .

Table 1 pointed out that the minimum of CA coefficient is 0.813 , which is more than 0.7 ; hence, all constructs in the research archived the reliability. Moreover, the lowest CR of all constructs in the study is 0.886 , which is more than 0.7. The minimum AVE is 0.723 , which is higher than 0.5. Moreover, the minimum outer loading of each construct in the research is more than 0.708 . Consequently, the constructs got convergent validity. Table 2 showed the HTMT value between each pair of the construct in the study. The maximum of HTMT is 0.772 , which is smaller than 0.85 . From this result, all constructs archived the discriminant validity.

Table 2. The HTMT value

\begin{tabular}{|l|c|c|c|c|}
\hline & CR & DRB & FSE & ITP \\
\hline DRB & 0.409 & & & \\
\hline FSE & 0.402 & 0.409 & & \\
\hline ITP & 0.772 & 0.629 & 0.736 & \\
\hline SMC & 0.423 & 0.492 & 0.550 & 0.684 \\
\hline
\end{tabular}


After check the reliability and validity of constructs in the study, the research will test the hypotheses and theoretical model. Hair et al. (2016) suggested the process to test the Partial Least Squares Structural Equation Modeling (PLS-SEM), which has the bootstrap procedure with 5000 random subsamples, including 05 steps below.

Step 1. Assess the VIF value to ensure that there is no collinearity in the research model. The threshold of VIF value is lower than 5. All the VIF value in Table 3 is smaller than 5; hence, the constructs in the research model do not have collinearity with the others.

Table 3. The result of VIF, $\mathrm{R}^{2}, \mathrm{f}^{2}$, and $\mathrm{Q}^{2}$.

\begin{tabular}{|l|c|c|c|c|c|c|}
\hline & \multicolumn{2}{|c|}{ VIF } & \multirow{2}{*}{$\mathrm{R}^{2}$} & \multicolumn{2}{|c|}{$\mathrm{f}^{2}$} & \multirow{2}{*}{$\mathrm{Q}^{2}$} \\
\cline { 1 - 1 } \cline { 5 - 6 } & $\mathrm{CR}$ & $\mathrm{ITP}$ & & $\mathrm{CR}$ & $\mathrm{ITP}$ & \\
\hline CR & & 1.000 & 0.225 & & 0.967 & 0.165 \\
\hline DRB & 1.291 & & & 0.044 & & \\
\hline FSE & 1.380 & & & 0.032 & & \\
\hline ITP & & & 0.492 & & & 0.321 \\
\hline SMC & 1.499 & & & 0.036 & & \\
\hline
\end{tabular}

Step 2. Assess the path coefficient between the two constructs. The p-value of the valid path coefficient is less than 0.05 . The path coefficients in Table 4 archived significantly with the p-value is less than 0.05 .

Table 4. The result of PLS-SEM

\begin{tabular}{|l|c|c|c|c|c|c|}
\hline & Beta & STDEV & T Statistics & P Values & H & Result \\
\hline CR -> ITP & 0.701 & 0.036 & 19.454 & 0.000 & H1 & Accepted \\
\hline DRB -> CR & 0.211 & 0.050 & 4.222 & 0.000 & H2 & Accepted \\
\hline SMC -> CR & 0.204 & 0.053 & 3.863 & 0.000 & H3 & Accepted \\
\hline FSE -> CR & 0.185 & 0.059 & 3.164 & 0.002 & H4 & Accepted \\
\hline
\end{tabular}

Note: Standard Deviation (STDEV), t-statistics $(|O / S T D E V|)$, Hypothesis $(H)$

Step 3. Assess the Coefficient of Determination via $\mathrm{R}^{2}$ Value. The Coefficient of Determination is shown the amount of variance in the relationship between all of the exogenous constructs and the endogenous construct. $R^{2}$ values of $0.75,0.50$, or 0.25 , respectively, described as substantial, moderate, or weak. The CR and the ITP have been explained by $22.5 \%$ and $49.2 \%$ by the change of independent variables. According to Hair et al. (2016), the $\mathrm{R}^{2}$ value can be accepted with 0.2 in behavioral science.

Step 4. Assess the effect size through $\mathrm{f}^{2}$ value. This criterion is a criterion that is encouraged by journal editors and reviewers in the recent period. The $\mathrm{f}^{2}$ value will evaluate whether the omitted construct has a substantive impact on the endogenous constructs. The $\mathrm{f}^{2}$ values of $0.02,0.15$, and 0.35 , respectively, represent small, medium, and large effects of the exogenous latent variable. The CR has the large effect size on the ITP (0.967); DRB, FSE, SMC have the small effect size on CR with $\mathrm{f}^{2}$ value, respectively, are $0.044,0.032,0.036$ (Table 3)

Step 5. Assess of Predictive Relevance via $\mathrm{Q}^{2}$ value. Predictive Relevance predicts the model's outof-sample. $\mathrm{Q}^{2}$ values larger than 0 pointed out that the model has predictive relevance for a certain endogenous construct. Table 3 also pointed out all $\mathrm{Q}^{2}$ value are more than $0\left(\mathrm{Q}^{2} \mathrm{CR}=0.165, \mathrm{Q}^{2}{ }_{\mathrm{ITP}}=0.321\right)$

Moreover, Table 5 showed that the customer relationship is also a partial mediator in the relationship between its antecedents and intention to purchase in the designed fashion context. The customer relationship is satisfied with four criteria (Andrews et al., 2004):

Criterion (1): DRB, SMC, FSE have significantly impact on CR

Criterion (2): CR has significantly impact on ITP

Criterion (3): DRB, SMC, FSE have significantly impact on ITP (Table 5)

Criterion (4): The impact of DRB, SMC, FSE on ITP decrease in the relationship with CR. 
Table 5. The four criteria for proving the mediator

\begin{tabular}{|l|c|c|c|c|c|c|c|c|}
\hline \multirow{2}{*}{ Relationship } & \multicolumn{2}{|c|}{ Criterion 1 } & \multicolumn{2}{c|}{ Criterion 2 } & \multicolumn{2}{c|}{ Criterion 3 } & \multicolumn{2}{c|}{ Criterion 4 } \\
\cline { 2 - 9 } & Beta & P Values & Beta & P Values & Beta & P Values & Beta & P Values \\
\hline DRB -> CR & 0.211 & 0.000 & & & & & & \\
\hline SMC -> CR & 0.204 & 0.000 & & & & & & \\
\hline FSE -> CR & 0.185 & 0.002 & & & & & & \\
\hline CR -> ITP & & & 0.701 & 0.036 & & & & \\
\hline DRB -> ITP & & & & & 0.183 & 0.000 & & \\
\hline FSE -> ITP & & & & & 0.310 & 0.000 & & \\
\hline SMC -> ITP & & & & & 0.204 & 0.000 & & \\
\hline DRB -> CR -> ITP & & & & & & & 0.085 & 0.001 \\
\hline FSE -> CR -> ITP & & & & & & & 0.074 & 0.004 \\
\hline SMC -> CR -> ITP & & & & & & & 0.083 & 0.000 \\
\hline
\end{tabular}

\section{Discussion}

The results of study have made a positive contribution to building the buying intent of customers in the field of fashion. Maintaining close relationships with customers is an essential factor for successful business growth. In the Age of Automation and Innovation, customer relationship has been more critical.

Firstly, the intention to purchase of designed fashion product will be effect by the customer relationship. Customer relationships will create customers' positive thoughts and impressions about a brand. Sometimes customers will only buy after a trial or create a relationship with the seller before the shopping behavior. The research result pointed out the customer relationship has the positive impact on the purchase intention (beta $=0.701, \mathrm{p}$-value $=0.000$ ). Therefore, hypothesis H1 is accepted. This result affirmed the important role of CRM strategies in today's context, which has been confirmed through previous studies (Sheth and Parvatlyar, 1995; Palmatier et al., 2006; Kim and Ko, 2010). Stay in touch, and give customers something valuable to exchange with time, attention. These values do not need to be excessive. The customer can be an offer, announcements about a special event, insights, and helpful advice or customer information that can be used by all customers. Especially, the mental benefits as shopping enjoyment, the perceived control in shopping are significant for the fashion business to gain success (Nguyen and Khoa, 2019a).

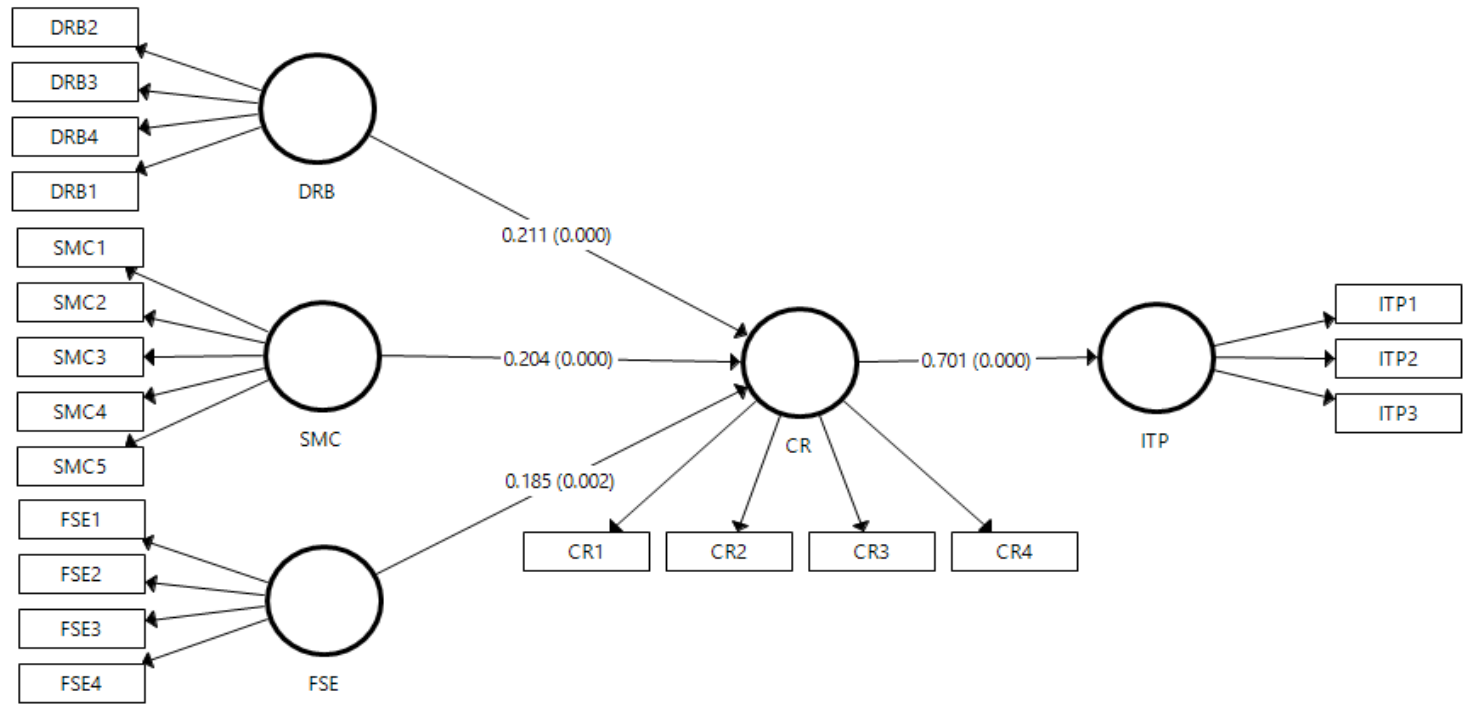

Figure 2. The result of the research model 
Secondly, the result showed that the designer reputation belief has a positive impact on the customer relationship (beta $=0.221$, p-value $=0.000$ ). The hypothesis $\mathrm{H} 2$ is accepted. Fashion design depends a lot on the personality and characteristics of the designer. A famous designer can be reputable enough to create trust and engage with that designer in the process of buying fashion products (Hilton et al., 2004; Sterlacci, 2019).

Thirdly, marketing media communication effect positively on the customer relationship (beta $=$ 0.204 , p-value $=0.000$ ). The hypothesis H3 is supported. Today's media is not only practiced in media such as newspapers, television but also extends to social media such as social networking tools. Kim and Ko (2010) also demonstrated that social media would impact customer relationships. Relationships have a short lifespan. One of the biggest mistakes is not keeping track of their customers after the sale (Khoa, 2020).

Finally, the store environment is one of the key factors effect on the customer relationship (beta $=$ 0.185 , p-value $=0.002$ ). Hence, the hypothesis H4 is supported. The difference in the store environment will lead to different customer behaviors (Scarpi, 2006). Most businesses claim to offer customers a unique experience, but very rarely do they do that. Others can do quite well, but they do not come from defining what the customer wants. Only when the business truly understand what the customer wants and try to meet it fully or exceed expectations, is it when the business creates valuable customer experiences.

\section{Contribution and Implication}

\subsection{Contribution of the study}

This research has discovered customer behavior in the field of fashion, specially designed fashion, a limited research field. Through quantitative research with 586 survey participants, the results have contributed that the designer reputation belief, social marketing communication, and the store environment have a positive impact on the customer relationship. Besides, customer relationship is the mediator in the relationship marketing between the designer reputation belief, social marketing communication, the store environment, and intention to purchase. Relationships are an indispensable element in branding. Even if the business has a well-defined target audience, it ignores the basic needs and does not need to satisfy its customers' needs, and they will leave. Customers know what they want, and if they do not get it, they will choose competitors of business to buy products or services. Do not let customers leave the business. Instead, dig a little deeper and give them something unique, which means a close customer relationship.

\subsection{Managerial implications}

Belief plays a significant role in business. Designer reputation belief can add value, save time, cut costs, and increase profits for both sellers and customers. However, to build trust, one thing is often forgotten that "customers will never trust young designers easily." The designer should be open and honest or should know and put in the customers to better understand them. Fashion designers should learn how to create idea boards and product ranges to build a reputation. Designers need to be good at researching fashion trends and finding inspiration from social networking sites, comparing prices and quality of various brands and trade shows. In addition, designers should be willing to spend much time perfecting their skills. A little practice every day will help the designer gain in-depth knowledge in the long run to create a reputation for himself.

There are many solutions to improve marketing media communication. Fashion businesses should immediately connect with customers through signing up for the newsletter via the fan page by clicking "like the page." At the same time, businesses should take time to turn designers' networks with connected fans into customers. The salesperson can give the customers advice about the fashion style through social networking sites or forums to create an enjoyable and long-term relationship.

The relationship between the customers and the fashion designer can improve through the store environment. Enterprises need to train professional fashion salespeople with counseling skills, communication skills. Besides, the arrangement of fashion products should also enhance the science so that customers can easily choose the products they need. In addition, the use of color lights, music at the store should be appropriate to the age, and social class of customers. 


\section{Limitations and direction for future research}

For research on the field of design, fashion is still relatively new in Vietnam, so the topic still has some limitations, which are the directions for further studies. First, customer relationship research can be implemented as a multi-dimensional concept to understand better and conceptualize this concept. Also, the consequences of a relationship can be discovered at specific behavior after the first purchase is an acquisition, word of mouth, or customer loyalty. At the same time, the scope of research can be expanded in countries with developed fashion industries to understand better the orientation of the relationship between fashion customers and designers.

\section{Reference}

Ajzen, I. (1991). The theory of planned behavior. Organizational behavior and human decision processes, 50, 179-211.

Ajzen, I. \& Fishbein, M. (1975). Belief, attitude, intention and behavior: An introduction to theory and research. Reading, MA: Addison-Wesley.

Andrews, J. C., Netemeyer, R. G., Burton, S., Moberg, D. P. \& Christiansen, A. (2004). Understanding adolescent intentions to smoke: An examination of relationships among social influence, prior trial behavior, and antitobacco campaign advertising. Journal of Marketing, 68, 110-123.

Blackwell, R. D., Miniard, P. W. \& Engel, J. F. (2006). Consumer behavior, Mason, OH, Thomson/South-Western.

Brink, A. \& Berndt, A. (2009). Relationship marketing and customer relationship management, Cape Town, South Africa, Juta and Company Ltd.

Dunne, P. M., Lusch, R. F. \& Carver, J. R. (2013). Retailing, Massachusetts, US, Cengage Learning.

Edosomwan, S., Prakasan, S. K., Kouame, D., Watson, J. \& Seymour, T. (2011). The history of social media and its impact on business. Journal of Applied Management and entrepreneurship, 16, 79-91.

Engel, J., Blackwell, R. \& Kollat, D. (1982). Consumer Behavior. Engel Consumer Behavior.

Gronroos, C. (2007). Service management and marketing: Customer management in service competition, Chichester, Wiley.

Hair, J. F., Hult, G. T. M., Ringle, C. \& Sarstedt, M. (2016). A primer on partial least squares structural equation modeling (PLS-SEM), London, Sage publications.

Hansen, T., Jensen, J. M. \& Solgaard, H. S. (2004). Predicting online grocery buying intention: a comparison of the theory of reasoned action and the theory of planned behavior. International Journal of Information Management, 24, 539-550.

Hilton, B., Choi, C. J. \& Chen, S. (2004). The ethics of counterfeiting in the fashion industry: quality, credence and profit issues. Journal of Business Ethics, 55, 343-352.

Jobber, D., Lancaster, G. \& Meunier-FitzHugh, K. L. (2019). Selling and Sales Management, UK, Pearson.

Kaplan, A. M. \& Haenlein, M. (2010). Users of the world, unite! The challenges and opportunities of Social Media. Business horizons, 53, 59-68.

Kawamura, Y. (2004). The Japanese revolution in Paris fashion. Fashion theory, 8, 195-223.

Khoa, B. T. (2018). The Impact of Perceived Risk on the Customer's Online Purchasing Intention in Ho Chi Minh city. Journal of Science and Technology, 34, 87 - 97.

Khoa, B. T. (2020). The Antecedents of Relationship Marketing and Customer Loyalty: A Case of the Designed Fashion Product. The Journal of Asian Finance, Economics and Business, 7, 195-204.

Kim, A. J. \& Ko, E. (2010). Impacts of luxury fashion brand's social media marketing on customer relationship and purchase intention. Journal of Global Fashion Marketing, 1, 164-171.

Kutner, S. \& Cripps, J. (1997). Managing the customer portfolio of healthcare enterprises. Healthcare Forum Journal, 40, $52-54$.

Lovelock, C. H. \& Wirtz, J. (2008). Services marketing: People, technology, strategy, New Jersey, Prentice-Hall.

Macintosh, G. \& Lockshin, L. S. (1997). Retail relationships and store loyalty: a multi-level perspective. International Journal of Research in marketing, 14, 487-497.

Marzo-Navarro, M., Pedraja-Iglesias, M. \& Rivera-Torres, M. P. (2004). The benefits of relationship marketing for the consumer and for the fashion retailers. Journal of fashion marketing and management, 8, 425-436.

Morgan, R. M. \& Hunt, S. D. (1994). The commitment-trust theory of relationship marketing. The journal of marketing, $58,20-38$.

Murthy, D. (2012). Towards a sociological understanding of social media: Theorizing Twitter. Sociology, 46, 1059-1073.

Nguyen, H. M. \& Khoa, B. T. (2019a). Perceived Mental Benefit in Electronic Commerce: Development and Validation. Sustainability, 11, 6587-6608.

Nguyen, H. M. \& Khoa, B. T. (2019b). The Relationship between the Perceived Mental Benefits, Online Trust, and Personal Information Disclosure in Online Shopping. The Journal of Asian Finance, Economics and Business, 6, 261-270.

Nguyen, M. H. \& Khoa, B. T. (2019c). Customer Electronic Loyalty towards Online Business: The role of Online Trust, Perceived Mental Benefits and Hedonic Value. Journal of Distribution Science, 17, 81-93. 
Nguyen, M. H. \& Khoa, B. T. (2019d). Perceived mental benefits of online shopping. Journal of Science, 14, 3-17.

Ou, W.-M., Shih, C.-M., Chen, C.-Y. \& Tseng, C.-W. (2012). Effects of ethical sales behaviour, expertise, corporate reputation, and performance on relationship quality and loyalty. The Service Industries Journal, 32, 773-787.

Palmatier, R. W., Dant, R. P., Grewal, D. \& Evans, K. R. (2006). Factors influencing the effectiveness of relationship marketing: a meta-analysis. Journal of marketing, 70, 136-153.

Parsons, A. G. (2011). Atmosphere in fashion stores: do you need to change? Journal of fashion marketing and management: An international journal, 15, 428-445.

Reinartz, W. J. \& Kumar, V. (2003). The impact of customer relationship characteristics on profitable lifetime duration. Journal of marketing, 67, 77-99.

Scarpi, D. (2006). Fashion stores between fun and usefulness. Journal of Fashion Marketing and Management: An International Journal, 10, 7-24.

Sheth, J. N. \& Parvatlyar, A. (1995). Relationship marketing in consumer markets: antecedents and consequences. Journal of the Academy of marketing Science, 23, 255-271.

Srinivasan, R. \& Moorman, C. (2005). Strategic firm commitments and rewards for customer relationship management in online retailing. Journal of Marketing, 69, 193-200.

Sterlacci, F. (2019). What is fashion designer? [Online]. Available: https://fashion-history.lovetoknow.com/fashionclothing-industry/what-is-fashion-designer [Accessed September 12 2019].

Teece, D. J. (1998). Capturing value from knowledge assets: The new economy, markets for know-how, and intangible assets. California management review, 40, 55-79.

Widyarini, L. A. \& Gunawan, S. (2017). Predicting consumer purchase intention on fashion products in online retailer: integration of self-determination theory and theory of planned behavior. Int J Emerg Res Manag Technol, 6, 7-18.

Zinko, R., Ferris, G. R., Humphrey, S. E., Meyer, C. J. \& Aime, F. (2012). Personal reputation in organizations: Two-study constructive replication and extension of antecedents and consequences. Journal of Occupational and Organizational Psychology, 85, 156-180. 